\title{
PENGARUH PELATIHAN DAN PENGEMBANGAN KARIR TERHADAP KINERJA KARYAWAN PT INTERPAK GLOBAL CANINDO BEKASI
}

\author{
Rosmalinda 1 ) \\ 1) Mahasiswa Program Studi Manajemen FE. UNKRIS \\ Arief Syah Safrianto ${ }^{2)}$ \\ 2) Dosen Program Studi Manajemen FE UNKRIS \\ Alamat: Kampus UNKRIS, Jatiwaringin Jakarta Timur \\ Email: ariefsafrianto@gmail.com
}

\begin{abstract}
The purpose of this research is to discover whether there is an effect of training and career development on employee performance either simultaneously and partially. This study is also to compare and improve the results of previous studies. This study was conducted on 63 respondence at PT. Interpak Global Canindo. Data acquisition was using questionnaire with Likert scale. The sampling technique was using saturated samples. From the result, it was found the fact that training and career development simultaneously and partially have a significant effect on employee performance. furthermore, training and career development partially also had a significant effect on employee performance.
\end{abstract}

Keywords: Training, career development and employee performance

\section{PENDAHULUAN}

Sumber Daya Manusia merupakan peran penting yang harus diperhatikan oleh perusahaan. Sumber daya manusia yakni salah satu Aset utama perusahaan, sehingga perusahaan dapat terus berkembang. Dengan memiliki sumber daya manusia yang berkualitas maka perusahaan akan mampu mengembangkan kegiatan usahanya dengan lebih baik, sumber daya manusia merupakan pelaksana dari semua kebijakan organisasi, sehingga perlu memiliki pengetahuan dan keterampilan yang memadai. Sumber daya manusia penting disadari oleh semua tingkatan manajemen perusahaan.

Sumber daya manusia yang berkualitas adalah sumber daya manusia yang memiliki pengetahuan, kemampuan, keterampilan dan sikap kerja yang baik. Organisasi perlu mengambil tindakan untuk mengembangkan dan meningkatkan kualitas karyawan. Karyawan adalah sumber daya manusia yang terlibat langsung dalam kegiatan perusahaan/ organisasi. Melalui kegiatan pelatihan, karyawan memiliki kesempatan untuk menyerap ilmu atau nilai-nilai baru, sehingga karyawan dapat menggunakan pengetahuan baru tersebut untuk meningkatkan tingkat profesionalnya dalam menjalankan tugasnya. Dengan kemajuan teknologi saat ini, faktor manusia masih memegang peranan penting dalam keberhasilan suatu organisasi. Interpak terus berkomitmen untuk berinovasi dengan mengembangkan kemasan yang lebih ekonomis, serta ramah lingkungan dan untuk kebutuhan pelanggan. Composite adalah kemasan kaleng yang bahan utamanya adalah kertas kraft. Composite dapat digunakan untuk kemasan produk makanan dan produk non makanan. Interpak menyediakan berbagai tipe kemasan yang dipilih sesuai dengan kebutuhan pelanggan. Visi interpak adalah 
terus mengembangkan kemasan yang sesuai dengan kebutuhan pelanggan atau pasar dengan produk yang variatif, inovatif, berkapasitas besar serta efisien. Interpak terus berupaya memenuhi standar kualitas internasional bagi para pesaing di pasar global serta pula produk interpak telah banyak masuk pasar ekspor ataupun pasar global. Interpak memberikan solusi dalam menentukan kemasan yang tepat dan sesuai dengan dengan kebutuhan produk planggan seperti design label dengan finishing yang bervariasi. Hal ini untuk memastikan setiap produk harus mempunyai nilai jual yang tinggi dan mampu meningkatkan penjualan. Untuk mencapai visi serta misi perusahaan, Interpak senantiasa berupaya membangun reputasinya dengan produk yang berkualitas, pengiriman tepat waktu, harga yang kompetitif dan sensus purna jual yang baik. Moto Interpak adalah kesuksesan anda adalah kesuksesan kami dan jika anda menjadi besar maka saya juga hebat. Setiap bisnis pasti memiliki tujuan yang ingin dicapai dalam kerangka waktu tertentu. Untuk mencapai tujun yang dimaksud, setiap perusahaan harus memiliki sumber daya manusia yang memadai. Kinerja adalah ukuran bagaimana tujuan organisasi telah tercapai. Meningkatkan kinerja karyawan dalam organisasi salah satunya memberikan program pelatihan dan pengembangan karir kepada karyawan.

Selain memegang peran penting, sumber daya manusia juga memiliki sejumlah faktor negatif jika tidak dikelola dengan baik. Efisiensi yang tidak terkendali dan efektivitas kerja yang rendah yang menggakibatkan penurunan produktivitas perusahaan merupakan dampak yang paling kecil jika sumber daya manusia yang tidak terkontrol dengan baik. Perhatian harus diberikan pada masalah yang berkaitan dengan sumber daya manusia dalam organisasi. Jika suatu perusahaan atau organisasi menginginkan keunggulan Sumber daya manusia yang dapat bersaing, maka perusahaan harus senantiasa menciptakan konsep pelatihan dan pengembangan karir Sumber Daya Manusia secara terus menerus. Hal ini menunjukan tanpa didukung dengan kerja yang baik dari karyawan dalam melaksanakan setiap tugasnya, maka keberhasilan organisasi tidak akan tercapai serta kontribusi pegawai pada organisasi akan menentukan maju atau mundurnya suatu organisasi. konsep tersebut tidak bisa dinaikan bagi perusahaan yang ingin menjadikan Sumber daya manusia sebagai sumber keunggulan yang dapat bersaing.

Kinerja karyawan merupakan salah satu tuntutan manajemen atas tugas yang diberikan dalam mencapai tujuan utama perusahaan. Dengan prestasi kerja yang tinggi diharapkan perusahaan dapat berdaya saing dan unggul dari para persaingnya, sehingga mampu bertahan dan kompeten. Oleh karena itu, untuk mencapai tujuan tersebut manajemen membutuhkan sumber daya manusia sebagai salah satu aset berharga yang dimiliki parusahaan. Dengan adanya dukungan penuh dari karyawan dalam melaksanakan tugasnya diharapkan perusahaan dapat maksimalkan pencapaian tujuan untuk maju dan berkembang. Pelatihan dan pengembangan karir adalah salah satu bagian terpenting dalam elemen manajemen Sumber Daya Manusia di sebuah perusahaan. Jika sebuah perusahaan atau organisasi menginginkan keunggulan SDM yang dapat bersaing sebagai sumber keunggulan kompetitif, maka perusahaan harus memuat konsep pelatihan dan pengembangan karir SDM secara terus menerus. Pelatihan adalah rangkaian yang dilakukan untuk mengetahui perubahan karyawan secara sistematis untuk mencapai tujuan organisasi.

Permasalahan yang terjadi di PT Interpak Global Canindo yaitu perusahaan dihadapkan dengan permasalahan kinerja 
karyawan yang menurun seperti kualitas dan kuantitas pekerjaan yang dihasilkan masih kurang sempurna sehingga banyak pembatan pemesanan oleh konsumen dan ketepatan waktu dalam produksi masih kurang maksimal sehingga terdapat pembatalan pesanan. Hal ini menyebabkan target pekerjaan yang telah ditetapkan untuk setiap pekerjaan masih belum sempurna mencapai target dan sangat berpengaruh terhadap menurunnya pencapaian penjualan perusahaan. PT Interpak Global Canindo mencapai target hanya pada bulan januari - Februari. Sebagaimana permasalahan yang ada, faktor yang dapat mempengaruhi kinerja karyawan adalah Pelatihan dimana karyawan perlu adanya program pelatihan untuk memberikan bekal kepada setiap karyawan agar dapat menjalankan pekerjaan dengan maksimal, dan memberikan program pengembangan karir untuk menyiapkan karyawan agar bisa mendapat menghadapi permasalahanpermasalahan yang akan dihadapi di masa yang akan datang.

Tujuan Penelitian untuk mengetahui dan menganalisis pengaruh pelatihan dan pengembangan karir terhadap kinerja karyawan pada PT Interpak Global Canindo

\section{LANDASAN TEORI}

\section{Kinerja Karyawan}

Istilah kinerja berasal dari kata job performance atau actual performance prestasi kerja atau prestasi sesungguhnya yang dicapai oleh seseorang. Yang dimaksud kinerja adalah kualitas dan kuantitas pekerjaan yang dilakukan oleh seorang karyawan dalam melaksanakan tugasnya sesuai dengan tugas yang diberikan kepadanya.

Indikator untuk mengukur kinerja karyawan secara individu ada lima indikator, yaitu (Robbins, 2016): 1). Kualitas; Kualitas kerja diukur dari persepsi karyawan terhadap kualitas pekerjaan yang dihasilkan dan tingkat kelengkapan tugas dan keterampilan dan kemampuan karyawan. 2). Kuantitas; Merupakan jumlah produksi yang dinyatakan dalam jumlah unit, jumlah siklus aktivitas yang diselesaikan. 3). Ketepatan waktu; Merupakan aktivitas diselesaikan pada awal waktu yang dinyatakan, dilihat dari sudut koordinasi dangen hasil output serta memaksimalkan waktu nag tersedia untuk aktivitas lain. 4). Efektifitas; Merupakan tingkat penggunaan sumber daya organisasi (tenaga, uang, teknologi, bahan baku) dimaksimalkan dengan maksud menaikkan hasil dari setiap unit dalan penggunaan sumber daya. 5). Kemandirian; Merupakan tingkat seorang karyawan yang nantinya akan dapat menjalankan fungsi kerjanya.

\section{Pelatihan}

Menurut Rivai dan Sagala (2011), pelatihan adalah proses mengubah perilaku karyawan secara sistematis untuk mencapai tujuan organisasi. Pelatihan berkaitan dengan keterampilan dan kemampuan karyawan dalam pekerjaannya saat ini. Pelatihan merupakan proses peningkatan kemampuan karyawan dan melatih kemampuan, keterampilan dan pengetahuannya agar dapat melaksanakan pekerjaan secara efektif dan efisien untuk mencapai tujuan perusahaan.

Indikator pelatihan menurut Mangkunegara (2012), antara lain: 1). Instruktur; a). Pendidikan lebih ditunjukan pada peningkatan kemampuan seseorang melalui jalur formal dengan jangka waktu yang panjang, guna mengoptimalkan penyampaian materi kepada peseta pelatihan. b). Kemampuan Instruktur dalam Penguasaan materi merupakan hal yang penting untuk dapat melakkan proses pelatihan dengan baik, sehingga materi dapat tersampaikan kepada peserta. 2). Peserta; Peserta pelatihan adalah karyawan perusahaan 
yang memenuhi persyaratan seperti karyawan yang semangat mengikuti pelatihan merupakan salah satu faktor yang menentukan proses pelatihan. Jika instruktur bersemangat dalam memberikan materi pelatihan maka peserta pelatihan pun akan bersemangat mengikuti program pelatihan tersebut, dan sebaliknya. Dan melakukan seleksi sebelum melaksanakan program pelatihan, yaitu pemilihan sekelompok orang yang paling memenuhi kriteria untuk posisi yang tersedia di perusahaan. 3). Materi; Materi yang diberikan dalam program pelatihan kepada peserta pelatihan harus sesuai dengan tujuan pelatihan, kompenen peserta dan penetapan sasaran, sehingga mampu mendorong peserta pelatihan untuk mengaplikasikan materi yang telah disampaikan dalam pelaksanaan pekerjaannya. 4). Metode yang digunakan; Metode penyampaian sesuai dengan materi yang hendak disampaikan, sehingga diharapkan peserta pelatihan dapat menangkap maksud dan tujuan dari apa yang disampaikan oleh Instruktur. Serta memiliki sasaran yang jelas agar lebih menjamin berlangsungnya kegiatan pelatihan sumber daya manusia yang efektif. 5). Tujuan pelatihan; Tujuan pelatihan harus spesifik dan terukur, sehingga pelatihan yang akan dipromosikan bertujuan untuk meningkatkan keterampilan kerja agar peserta dapat mencapai kinerja terbaik dan memperdalam pemahamannya tentang etika profesi yang harus diterapkan.

\section{Pengembangan Karir}

Pengembangan karir pada dasarnya ditujukan untuk pengembangan organisasi/ perusahaan untuk memenuhi tentangan bisnis masa depan. Setiap organisasi/ perusahaan harus menerima kenyataan bahwa keberadaannya dimasa depan bergantung pada sumber daya manusia (Nawawi, 2006). Tanpa sumber daya manusia yang kompetitif, organisasi akan mengalami kemunduran dan pada akhirnya akan terpinggirkan karena ketidak mampuannya menghadapi pesaing. Kondisi tersebut menurut organisasi/perusahaan melakukan pengembangan karir bagi karyawannya yang harus dilakukan secara terencana dan berkelanjutan.

Indikator pengembangan karir menurut Sihotang (2006) yaitu: 1). Kebijakan Organisasi; Merupakan yang paling dominan dalam mempengaruhi pengembangan karir seseorang karyawan dalam perusahaan. Kebijakan perusahaan merupakan penentu ada tidaknya pengembangan karir dalam perusahaan. 2). Prestasi kerja; Prestasi kerja merupakan bagian penting dari pengembangan karir seorang karyawan. Karyawan yang mempunyai prestasi kerja baik dalam perusahaan biasanya mendapatkan promosi jabatan, karena prestasi kerja merupakan salah satu acuan bagi organisasi dalam melakukan pengembangan karir. 3). Latar belakang pendidikan; Latar belakanng pendidikan merupakan salah satu bahan acuan bagi perusahaan untuk meningkatkan karir seorang karyawan, semakin tinggi latar belakang pendidikan seorang karyawan maka semakin besar pula harapan peningkatan karir nya, juga sebaliknya semakin rendah tingkat pendidikan seorang karyawan maka biasanya akan susah mendapatkan pengembangan karir nya. 4). Pengalaman kerja; Pengalaman kerja merupakan bagian penting dari pengembangan karir yang berguna untuk dapat memberikan kontribusi di berbagai posisi pekerjaan. 5). Kesetiaan pada organisasi; Kesetiaan pada organisasi merupakan tingkat kesetiaan atau loyalitas seorang karyawan pada perusahaa, semakin lama karyawan bekerja pada perusahaan loyalitasnya tinggi. Loyalitas atau kesetiaan juga berguna untuk mengurangi turn over karyawan. 6). Keluwesan bergaul dan berhubungan antar manusia; Merupakan kebutuhan seseorang untuk dihormati dan diakui 
keberadaannya baik oleh lingkungan internal maupun eksternal perusahaan.

\section{METODE PENELITIAN}

\section{Rancangan Penelitian}

Penelitian yang dilakukan pada penelitian ini menggunakan teknik analisis data kuantitatif. Penelitian ini dipilih karena berguna untuk mengetahui seberapa besar pengaruh Pelatihan dan Pengembangan karir terhadap kinerja karyawan di PT Interpak Global Canindo.

\section{Metode Pengumpulan Data}

Metode pengumpulan data dalam penelitian ini adalah: 1). Data primer; Studi lapangan atau data primer mencakup sumber data yang langsung peneliti dapatkan dari keadaan langsung dilapangan. Keunggulan data primer adalah menunjukan kenyataan atau realita berdasarkan apa yang terjadi dan hasil yang di dengar langsung oleh peneliti, sehingga dapat meminimalisir dan menghindari elemen kesalahan dari fenomena. Pada studi lapangan, ada beberapa metode yang digunakan guna memperoleh data primer, yaitu: a). Observasi. b). Wawancara. c). Koesioner. 2). Data Sekunder; Sugiyono (2017) mengatakan bahwa data sekunder merupakan sumber data yang tidak langsung memberikan data kepada pengumpul data, misalnya melalui orang lain atau lewat dokumen. Sumber data sekunder digunakan untuk mendukung informasi yang didapatkan dari sumber data primer yaitu dari literatur, penelitian terdahulu, buku dan lain sebagainya.

Populasi dalam dalam penelitian ini adalah karyawan PT Interpak Global Canindo sebanak 63 orang. Adapun teknik pengambilan sampel yang digunakan dalam penelitian ini adalah sampling jenuh sebanyak 63 orang. Jumlah sampel diambil secara keseluruhan apabila jumlah populasi keseluruhan kurang dari 100 orang.

\section{HASIL PENELITIAN DAN PEMBAHASAN}

\section{Hasil Penelitian}

\section{Uji validitas}

Pengujian validitas ini dilakukan untuk menguji apakah tiap butir pernyataan telah mewakili indikator yang akan diteliti, persyaratan minimum untuk dapat dikatakan valid adalah $\mathrm{r}=0,30$. Jadi, apabila korelasi antara butir-butir item pernyataan dengan skor total kurang dari 0,30 , maka butiran dalam instrumen tersebut dapat dikatakan tidak valid. Uji validitas dilakukan dengan melihat korelasi antara skor masing-masing item pernyataan dengan skor total. (Sugiyono, 2017).

Dari perhitungan koefisien korelasi skor tiap butir pernyataan dari 63 responden tentang instrument pelatihan, dengan jumlah 10 pernyataan; instrumen pengembangan karir 12 pernyataan dan instrumen kinerja karyawan 10 pernyataan dengan total skor setiap responden diperoleh hasil $r$ hitung lebih besar dari $r$ kritis 0,300 .

\section{Uji reliabilitas}

Pengujian reliabilitas ini dilakukan untuk menguji seberapa jauh hasil pengukuran yang dapat diandalkan secara konsisten. Pada tabel hasil pengujian reliabilitas berikut, diketahui bahwa semua variabel mempunyai alpha di atas 0,6 yang berarti bahwa semua variabel dalam penelitian ini dapat diandalkan. 
Tabel 1 : Hasil Uji Reliabilitas Variabel

\begin{tabular}{lcc}
\hline \multicolumn{1}{c}{ Variabel } & Cronbach's Alpha & Keterangan \\
\hline Pelatihan & 0.932 & Reliabel \\
Pengembangan Karir & 0.929 & Reliabel \\
Kinerja Karyawan & 0.909 & Reliabel \\
\hline
\end{tabular}

Sumber: Hasil pengolahan data, 2021

Berdasarkan Tabel 1, angka-angka reliabilitas cronbach alpha tersebut tampak bahwa seluruh pernyataan yang ada membentuk ukuran yang reliabel,

\section{Analisis regresi linear berganda}

Tabel 2: Pengaruh Pelatihan dan Pengembangan Karir Terhadap Kinerja Karyawan PT. Interpak Global Canindo

\begin{tabular}{lcccccc}
\hline \multirow{2}{*}{ Variabel } & \multicolumn{6}{c}{ Parameter } \\
\cline { 2 - 7 } & $\begin{array}{c}\text { Mult. } \\
\text { R }\end{array}$ & $\begin{array}{c}\text { R } \\
\text { Square }\end{array}$ & Konstanta & $\begin{array}{c}\text { Koefisien } \\
\text { Regresi }\end{array}$ & Sig. & $\boldsymbol{\alpha}$ \\
\hline Pelatihan & 0,860 & 0,740 & 5,807 & 0,244 & 0,000 & 0,05 \\
$\begin{array}{l}\text { Pengemb_Karir } \\
\text { Pengujian Signifikan }\end{array}$ & & & 0,495 & 0,000 & \\
\hline F hitung = 85,200 & & & & 0,000 & \\
\hline
\end{tabular}

Keterangan: Variabel Kinerja_Karyawan

Sumber: data diolah 2021

Dari Tabel 2, hasil uji F tersebut dijelaskan dengan menggunakan taraf signifikan sebesar 5\% $(0,05)$. Dapat dilihat bahwa perolehan nilai $\mathrm{F}$ hitung sebesar 85.200 dengan nilai signifikan 0,000, berarti secara bersama-sama pelatihan dan pengembanan karir berpengaruh signifikan terhadap kinerja karyawan PT. Interpak Global Canindo. Nilai koefisien determinasi ( $R$ square) adalah 0,740, artinya pelatihan dan pengembangan karir memberikan kontribusi $74,0 \%$ terhadap kinerja karyawan PT. Interpak Global Canindo, sedangkan sisannya sebesar $26 \%$ disumbangkan oleh variabel lain diluar penelitian ini. yaitu pelatihan, pengembangan karir, dan kinerja karyawan membentuk ukuran yang reliabel dari masing-masing variabel. 


\section{Analisis regresi linear sederhana}

Tabel 3: Pengaruh Pelatihan Terhadap Kinerja Karyawan PT. Interpak Global Canindo

\begin{tabular}{lcccccc}
\hline \multirow{2}{*}{ Variabel } & $\mathbf{R}$ & $\begin{array}{c}\mathbf{R} \\
\text { Square }\end{array}$ & Konstanta & $\begin{array}{c}\text { Koefisien } \\
\text { Regresi }\end{array}$ & Sig & $\boldsymbol{\alpha}$ \\
\hline Pelatihan & 0,795 & 0,632 & 11,304 & 0,714 & 0,000 & 0.05 \\
\hline Pengujian Signifikan & \multicolumn{7}{c}{ Parameter } \\
\hline t hitung $>$ t tabel $=10,239>2,000$ & & & & \\
\hline
\end{tabular}

\section{Keterangan: Variabel Kinerja_karyawan}

Sumber: data diolah 2021

Tabel 3, nilai koefisien determinasi $\left(R^{2}\right)$ sebesar 0.632 , artinya pelatihan memberikan kontribusi sebesar 63,2\% kepada kinerja karyawan PT. Interpak Global Canindo, sedangkan sisanya sebesar 36,8\% disumbangkan variabel lain yang tidak diteliti.

Persamaan Regresi Y $=11,304+0,714$ $\left(\mathrm{X}_{1}\right)$

Pelatihan berpengaruh positif dan signifikan pada tingkat nyata $99 \%$ terhadap kinerja karyawan PT. Interpak Global. Koefisien pelatihan sebesar 0,714, artinya jika ada peningkatan pelatihan, maka kinerja karyawan PT. Interpak Global Canindo akan meningkat. Untuk menguji hubungan secara parsial variabel pelatihan terhadap kinerja karyawan PT. Interpak Global Canindo signifikan atau tidak dilakukan pengujian $t$ hitung dibandingkan dengan $t$ tabel dengan tingkat $\alpha=0,05$, hasilnya adalah $\mathrm{t}$ tabel $=$ 2,000. Berdasarkan perhitungan tersebut dapat dinyatakan bahwa nilai $\mathrm{t}$ hitung $=$ 10,239 dan $\mathrm{t}$ tabel $=2,000$ atau $\mathrm{t}$ hitung $>\mathrm{t}$ tabel $(10,239>2,000)$, maka Ho tolak dan $\mathrm{Ha}$ terima, dapat diartikan terdapat pengaruh yang positif dan signifikan variabel pelatihan terhadap kinerja karyawan PT. Interpak Global Canindo.

Tabel 4: Pengaruh Pengembangan Karir Terhadap Kinerja Karyawan PT. Interpak Global Canindo

\begin{tabular}{lcccccc}
\hline \multirow{2}{*}{ Variabel } & $\mathbf{R}$ & $\begin{array}{c}\text { R } \\
\text { Square }\end{array}$ & Konstanta & $\begin{array}{c}\text { Koefisien } \\
\text { Regresi }\end{array}$ & Sig & $\boldsymbol{\alpha}$ \\
\hline Pengem_Karir & 0,848 & 0,719 & 6,714 & 0,680 & 0,000 & 0.05 \\
\hline Pengujian Signifikan \\
\hline t hitung > t tabel = 4,974 > 2,000 \\
\hline $\begin{array}{l}\text { Keterangan: Variabel Kinerja_karyawan } \\
\text { Sumber: data diolah 2021 }\end{array}$
\end{tabular}

Tabel 4, nilai koefisien determinasi $\left(\mathrm{R}^{2}\right)$ sebesar 0.719 , artinya pengembangan karir memberikan kontribusi sebesar 71,9\% kepada kinerja karyawan PT. Interpak Global Canindo, sedangkan sisanya sebesar $28,1 \%$ disumbangkan variabel lain yang tidak diteliti.
Persamaan Regresi $\mathrm{Y}=6,714+0,680$

$\left(\mathrm{X}_{2}\right)$

Pengembangan karir berpengaruh positif dan signifikan pada tingkat nyata 99\% terhadap kinerja karyawan PT. Interpak Global Canindo. Koefisien pengembangan karir sebesar 0,680, 
artinya jika ada peningkatan pengembangan karir, maka kinerja karyawan PT. Interpak Global Canindo akan meningkat. Untuk menguji hubungan secara parsial variabel pengembangan karir terhadap kinerja karyawan PT. Interpak Global Canindo signifikan atau tidak dilakukan pengujian $t$ hitung dibandingkan dengan $\mathrm{t}$ tabel dengan tingkat $\alpha=0,05$, hasilnya adalah $\mathrm{t}$ tabel $=$ 2,000. Berdasarkan perhitungan tersebut dapat dinyatakan bahwa nilai $\mathrm{t}$ hitung $=$ 4,974 dan $\mathrm{t}$ tabel $=2,000$ atau $\mathrm{t}$ hitung $>\mathrm{t}$ tabel $(4,974>2,000)$, maka Ho tolak dan Ha terima, dapat diartikan terdapat pengaruh yang positif dan signifikan variabel pengembangan karir terhadap kinerja karyawan PT. Interpak Global Canindo.

\section{Pembahasan}

\section{Pengaruh Pelatihan dan Pengembangan Karir terhadap Kinerja Karyawan}

Hasil penelitian menunjukkan bahwa pelatihan dan pengembangan karir mendorong peningkatan kinerja karyawan. Penelitian ini sesuai dengan yang dilakukan oleh Halim (2019) yang menyatakan bahwa pelatihan dan pengembangan karir memiliki pengaruh positif dan signifikan terhadap kinerja karyawan pada PT Sentosa Plastik Medan. Didukung juga dengan penelitian yang dilakukam Mulyadi dan Hidayati (2018) yang menyatakan bahwa pelatihan dan pengembangan karir memiliki pengaruh positif dan signifikan terhadap kinerja karyawan PT Bank Negara Indonesia (persero) Tbk Samarinda.

\section{Pengaruh Pelatihan terhadap Kinerja karyawan}

Hasil penelitian menunjukkan bahwa pelatihan mendorong peningkatan kinerja karyawan. Hal ini dikarenakan oleh instruktur menyampaikan materi pada peserta secara optimal, menguasai materi yang disampaikan, peserta seangat mengikutinya, sebelum pelatihan peserta diseleksi, materi sesuai dengan tujuan dan tepat sasaran metode pelatihan memiliki sasaran yang jelas, dan tujuan dapat meningkatkan keterampilan peserta. Penelitian ini sesuai dengan penelitian yang dilakukan oleh Sofia (2020) yang menyatakan bahwa pelatihan memiliki pengaruh signifikan terhadap kinerja karyawan.

\section{Pengaruh Pengembangan Karir terhadap Kinerja Karyawan}

Hasil penelitian menunjukkan bahwa pengembangan karir mendukung peningkatan kinerja karyawan. Hal ini dikarenakan oleh prestasi kerja menjadi pertimbangan pengembangan karir, adanya kesempatan bagi karyawan untuk meningkatkan pengembangan karirnya, aanya kesetiaan terhadap perusahaan, kerjasama yang baik dan didukung jaringan kerja yang baik, peluang mengembangkan karir terbuka bagi semua karyawan. Penelitian ini sesuai dengan penelitian yang pernah dilakukan oleh Fizia dan Iman (2018) yang menyatakan pengembangan karir berpengruh terhadap kinerja karyawan pada PT Tri Megah Makmur.

\section{KESIMPULAN DAN SARAN}

\section{Kesimpulan}

Berdasarkan hasil penelitian yang dilakukan di PT. Interpak Global Canindo. Hasil dari penelitian terhadap pengaruh pelatihan dan pengembangan karir terhadap kinerja karyawan diatas dapat ditarik beberapa keseimpulan sebagai berikut: 1). Pelatihan dan pengembangan karir secara simultan memiliki pengaruh terhadap kinerja karyawan. 2). Pelatihan memiliki pengaruh secara parsial terhadap kinerja karyawan. 3). Pengembangan karir berperan dalam meningkatkan kinerja karyawan. 


\section{Saran}

Dari hasil penelitian pengaruh pelatihan dan pengembangan karir terhadap PT. Interpak Global Canindo, maka dapat dikemukakan saran sebagai berikut: 1). Hasil penelitian ini dapat dijadikan sebagai bahan pertimbangan perusahaan dalam membuat atau merumuskan kebijaksanaan tentang pelatihan dan pengembangan karir karyawan, kaitannya dengan kinerja karyawan. 2). Sebaiknya pimpinan PT. Interpak Global Canindo dapat memberikan penghargaan terhadap karyawan yang memiliki kinerja yang tinggi agar dapat mendorong peningkatan motivasi kerja karyawan yang belum menjalani program platihan dan pengembangan karir. 3). Disarankan kepada peneliti selanjutnya untuk lebih detail dalam menggunakan aspek-aspek Pelatihan dan Pengembangan Karir dikaitkan dengan variabel kinerja karyawan.

\section{DAFTAR PUSTAKA}

Fizia, Nurul dan Muhammad Imam Muttagijin, 2018. Pengaruh Pelatihan dan Pengembangan Karir Terhadap Kinerja Karyawan Pada PT. Tri Megah Makmur.

Halim, Karina Oktaviana, 2019. Pengaruh Pelatihan dan Pengembanagan Karir Terhadap Kinerja Karyawan pada PT. Sentosa Plastik Medan.

Mangkunegara, A. Anwar Prabu. 2012. Manajeman Sumber Daya Manusia. Bandung: PT. Remaja Rosdakarya.
Mulyadi, Rajib dan Tetra Hidayati, 2018. Pengaruh Perencanaan Karir, Pelatihan dan Pengembangan Karir Terhadap Kinerja Karyawan PT. Bank Negara Indonesia (Persero) Tbk Samarinda.

Nawari, Hadari. 2006. Evaluasi dan manajemen Kinerja Di Lingkungan Perusahaan dan Industri. Yogyakarta: Gadjah Mada Univercity Press.

Rivai, Veithzal dan Sagala. 2011. Manajemen Sumber Daya Manusia untuk perusahaan dari Teori ke Praktik. Jakarta: PT Raja Grafindo.

Robbins, P. Stephen. 2006. Perilaku Organisasi. Edisi Sepuluh. Diterjemahkan Oleh: Drs.Benyamin Molan. Jakarta: Erlangga.

Sihotang. 2007. Manajemen Sumber Daya Manusia Cetakan Pertama, Jakarta: PT Pradanya Paramitha.

Sofia. 2020. The Influence of Training and Career Development to Employee Performance Among Academic Civities at Sekolah Tinggi Ilmu Ekonomi Muara.

Sugiyono. 2017. Metode Penelitian kuantitatif, Kualitatif. dan R\&D. Bandung: CV. Alfabeta.

Wibowo. 2012. Manajemen Kinerja. Jakarta: Raja Grafindo Persada. 